\title{
Parisli Bir Kasabın Erkeklik Halleri
}

\section{Uğur Ferhat Korkmaz}

Ankara Üniversitesi Sosyal Bilimler Enstitüsü

Radyo, Televizyon ve Sinema Anabilim Dalı

\section{Özet}

Kurgusal olandan yola çıkarak gerçek dünyayı yorumlamak, en nihayetinde hayali sonuçlar elde etmek anlamına gelebilir. Ancak kurgunun temelinde gerçek hayattan koparılamayacak kadar güçlü ve çoğu zaman yaratıcısının bile fark edemediği kodlar yatmaktadır. Bu kodlar eserin yaratıcısı tarafından hem kurgu içinde hem de gerçek hayatta birlikte kullanılabilir. İki dünyanın da (kurgu ve gerçek) birbiriyle sıkı bir etkileșim içinde olduğu düșünüldüğünde, bu kodlardan yola çıkılarak ortaya çıkarılan sonuçlar her iki dünya için de geçerli olabilir. Bu doğrultuda erkeklik meselesine dair birçok soru ve cevaba filmler üzerinden ulașmak mümkündür.

Bu çalıșma Gaspar Noé'nin yönettiği Carne (1991) ve Herkese Karșı Tek Bașına (1998) filmlerindeki "le Boucher" (Kasap) karakteri üzerinden erkek kimliğinin inșasına dair bazı konu bașlıklarına odaklanmaktadır. Filmler, gerçeklikle kurduğu sıkı bağla ortaya çıkan sonuçların gerçek hayata uyarlanmasını mümkün kılarken, bir erkek kahramanın bilinçdıșını açığa çıkartarak da erkeklik meselesine dair eșsiz bir çalıșma alanı sunmaktadır.

Anahtar Sözcükler: Erkeklik krizi, toplumsal cinsiyet ve yemek kültürü, kasaplık, hegemonik erkekliğin inșası, bilinç akıșı.

http://ilefdergisi.org/2014/1/1/

ilef dergisi · ilef journal • (c) $2014 \cdot$ 1(1) • bahar/spring: 89-114 


\section{A Parisian Butcher's Moods of Masculinity}

\section{Uğur Ferhat Korkmaz}

Ankara University Institute of Social Sciences

Department of Radio, Television and Cinema

\section{Abstract}

Interpreting the real world starting from a fictional one may finally lead to imaginary results. However, codes that are too strong to be separated from real life lie behind the fiction without their creator realizing this fact. These codes can be devised not only in fiction but also in the real world by their creator. When regarded, both these worlds are in a very strong interaction and the results based on these codes can be effective for both of the worlds. It is very likely to reach many questions and answers on the subject of masculinity in this direction, through such kind of movies.

This study focuses on some physical and social phases of the construction of hegemonic masculinity through "le Boucher" (Butcher) character in Corne (1991) and I Stand Alone (1998), movies of Gaspar Noe. These movies provide a unique view of masculinity crisis, revealing the subconscious of a male hero while making it possible to draw a parallel between fiction and non-fiction.

Keywords: Masculinity crisis, gender and food culture, butchery, construction of hegemonic masculinity, stream of consciousness.

\section{http://ilefdergisi.org/2014/1/1/}

ilef dergisi · ilef journal • (c) 2014 • 1(1) · bahar/spring: 89-114 


\section{Giriș}

Büyük bir makinenin değiştirilebilir bir parçası olmak istemiyorum.

Gaspar Noé' nin Fransa' da ve uluslararası alanda tanınmasını sağlayan ve sert eleştirilere maruz kalan ilk uzun metrajlı filmi I Stand Alone'dan (Herkese Karşı Tek Başına, 1998) alınan yukarıdaki cümle erkek kimliğinin inşasıyla ilgili bazı ipuçları verir. Bir erkek için sıradan olmak, görünmez olmak; yani büyük bir makinenin değiştirilebilir bir parçası olmak aynı zamanda gerçek bir erkek olmamak anlamına gelir. Çünkü erkek olmanın sürekli olarak sınanmak ve yeniden inşa edilmek gibi zorunlulukları vardır. Judith Butler'ın da belirttiği gibi, toplumsal cinsiyet aksiyonu tekrar edilen bir performans gerektirir ve söz konusu tekrar, toplumsal olarak tesis edilmiş bir dizi anlamın aynı anda hem yeniden icrası hem de yeniden deneyimidir. Bu imlemleri icra eden bedenler bireysel bedenler olsa da, bu eylem kamusal eylemdir. Dolayısıyla toplumsal cinsiyeti, zaman içerisinde zayıf bir inşayla kurulan, edimlerin stilize tekrarı üzerinden dış mekânda tesis edilen bir kimlik olarak tasavvur etmeliyiz (Butler 2012, s.229-230). Erkek-kamusal alan ve kadın-özel alan ayırımının temeli de erkeklik ve performans arasındaki bu ilişkiye dayanır. Söz konusu toplumsal cinsiyet performanslarına göre erkek olmak -kadın olmanın aksi- 
ne- görünür olmayı, daha da önemlisi toplum tarafından kabul gören, "meşru" bir kimlik için güçlü bir performans göstermeyi gerektirir.

Filmden alınan bu cümle, karakterin içinde bulunduğu sefil hayattan kurtulması için eril bir müdahalede bulunması gerektiğine işaret ederken, monologun tamamı ise erkek şiddetinin kaynağına dair önemli göndermeler içerir. Kasap, kendi kimliğinin inşası üzerine kurduğu bu cümlelerin ardından, erkek olmayı penis olmakla, kadın olmayı da vajina olmakla özetlediği bir analojiden sonra, içinde bulunduğu durumla erkeklik organının pasifliği arasında bir ilişki kurarak ${ }^{1}$, kurtuluşunu yine erkeklik organı ile fakat bu sefer aktifliği üzerinden kurduğu bağlantıya dayandırır. Bu monologdan sonra, eve gittiğinde hamile sevgilisinin karnını öldürücü darbelerle yumruklayarak bebeğini düşürmeye çalışacak ve o hayatı bir daha geri dönememek üzere geride birakacaktır.

Bu çalışmada Arjantin asıllı Fransız yönetmen Gaspar Noé'nin, şiddet eğilimli, kadın düşmanı, yabancı düşmanı, homofobik ve ensest arzulara sahip karakteri "le Boucher" (Kasap) üzerine kurulu iki filmi, Carne ${ }^{2}$ (1991) ve Herkese Karşı Tek Başına erkeklik tartışmaları çerçevesinde incelenecektir. Noé'nin ilk olarak, yaklaşık 40 dakikalık filmi Carne' de ortaya çıkardığı Parisli kasap karakteri, yönetmenin ilk uzun metrajlı filmi Herkese Karşı Tek Başına'nın da başkarakteri, aynı zamanda her iki anlatının merkezi konumundadır. Bu doğrultuda Carne ve Herkese Karşı Tek Başına iki ana başlık halinde ele alınacak ve erkeklik meselesi açısından incelenmeye değer temalar ön plana çıkarılarak ayrıntılı bir analiz yapılacaktır. Carne' de yalnız baba, kasaplık, et gibi temalar ön plandayken, Herkese Karşı Tek Başına' da ise işsizlik, milliyetçilik, homofobi, kadın düşmanlığıı, şiddet ve ensest ilişki ön plandadır. Aslında tüm bu alt başlıkların ilk filmden başlayarak, neredeyse kronolojik bir sıralama içinde kendini göstermesi tesadüf değildir. Birinin bittiği yerde diğerinin başlaması, ataerkil sistemin erkek kimliğinin zedelendiği durumlarda sistematik olarak nasıl yeni savunma mekanizmaları ortaya çıkardığına dair iyi bir örnektir. ${ }^{3}$

1 “Ben üzgün, üzgün bir kamışım ve biraz saygı duyulmak için her zaman kalkmış olmam lazım."

21991 Cannes Film Festivali'nde "SACD Award" adı altında en iyi kısa film ödülü aldı.

3 Ensest arzu meselesi bu kronolojinin dışında kalır. Şartlar ne kadar değişirse değişsin kasabın kızına karşı duyduğu ensest arzu her iki filmde de kendini gösterir. Ancak Herkese Karşı Tek Başına' da, ensest arzunun eyleme dönüştüğü sahne kronolojinin son halkasını temsil eder. Bu sahneyle birlikte kasabın erkek kimliği iflas eder, zaten bir parçası olamadığı toplumun ve toplumu temsil eden izleyicilerin arasına katılma şansını tamamen yitirir. 
$\mathrm{Bu}$ bağlamda, ortaya çıkarılan temaların yaratılan kasap karakterinin erkek kimliğini korumasında ve geliştirmesinde ne gibi işlevlere sahip olduğu, temalara uygun düşecek toplumsal cinsiyet çalışmalarının ışığında açığa çıkarılmaya çalışılacaktır. Ayrıca, belirlenen temaların erkek kimliği üzerindeki etkisinin sinematografik açıdan her iki filmde nasıl farklı biçimde ortaya konulduğuna yanıt aranacaktır. Her iki filmin çözümlenmesi aşamasında, erkekliğe dayalı performansların belirgin biçimde ortaya çıktığı sahneler belirlenerek göstergebilim ve psikanaliz gibi yapısalcı teorik çerçeve içinde feminist film teorisine uygun bir okuma yapılması amaçlanmaktadır. Erkeklik çalışmalarının, kadın düşmanlığına, homofobiye ve ataerkil erkekliklere karşı pro-feminist bir alan olduğu düşünüldügüunde sahnelerin çözümlenmesinde sıklıkla feminist okumalara başvurulacaktır. Özellikle ekofemizme dayalı metinlerle, doğa üzerindeki eril tahakkümün sinematografik yansımalarının her iki filmde nasıl kendini gösterdiği üzerinde durulacaktır.

\section{Carne, "Paris'in kenar mahallelerindeki bir at kasabının hikâyesi"}

Cannes Film Festivali'nde kazandığı ödül ve yarattığı etkiyle, Noé'nin ilk uzun metrajlı filmini çekmesi için gerekli olan finansmanı bulmasına kısmen de olsa yardımcı olan kısa filmi Carne, hem kurgusu hem de anlatı yapısı açısından farklı bir filmdir. Erkeklik tartışmaları için önemi ise filmin (anti)kahramanı olan kasabın sahip olduğu kişisel özellikler ve sergilediği performanstır. Filmin ilk 20 dakikası, sevgilisinin, kızları doğduktan sonra onları terk etmesiyle birlikte dilsiz kızını tek başına büyütmek zorunda kalan bir babanın hikayesi; sonraki 20 dakikalık bölüm ise dükkanını kaybetmiş, işsiz bir kasabın dramı olarak özetlenebilir. Kasap, film boyunca hem yalnız bir baba hem de işsiz bir erkek olarak kriz içindeki beyaz erkeğin portresini çizer. Bu portreyi farklı kılansa karakterin ve filmin içinde barındırdığı nihilist havadır. ${ }^{4}$

\section{Kadınsız, yalnız bir baba}

\section{O senin kızın, ben asla bir kız istemedim! $!^{5}$}

J. R. Macnamara, kitlesel ekonominin endüstri sonrası çağında teknolojik ve sosyal gelişimlerle paralel biçimde yeni imajlar ve yeni erkek kimliklerini kar-

4 Nihilizm tanımlaması Stephen Holden'ın New York Times'da Herkese Karşı Tek Başına filmi üzerine yazdığı bir eleştiriden ödünç alınmıştır. Holden (1998), filmin hiçbir filmin yapamadığı biçimde, acımasızca nihilizm psikolojisi içine daldığını, bunu da karakterin iç konuşmaları, çekim teknikleri, sarsıcı ses efektleri ile yaptığını ileri sürer. Bahsettiği özellikler her iki film için de geçerli olduğundan, nihilizm tanımını Carne' ye de uyarlayabiliriz.

5 Kasabın sevgilisi doğum yaptıktan hemen sonra kasaba bu sözleri söyler ve sonraki sahnede onları terk ettiğini yazan bir notu bebeğin içinde bulunduğu sepete bırakır. 
Şımıza çıkardığını söyler. Atlas Sendromu, işkolikler, bedavacı babalar, metroseksüeller ve kadınsı yönleri olan erkekleri de örnek olarak verir (Macnamara 2006, s.1). Akça ve Tönel, Atlas Sendromu'nun liberal feminizme bir eleştiri olarak ortaya çıkan 'süper kadın' kavramıyla benzerliğine dikkat çekerler (2011, s.13), Atlas Sendromu'nu ise şöyle açıklarlar:

Atlas Sendromu, erkeklerin yalnızca iş hayatında değil, aile hayatında da 'mükemmelliği' sağlama çabasının sonucunda ortaya çıkan psikolojik rahatsızlık olarak tanımlanmaktadır. (...)

21. Yüzyılla birlikte kadınların çalışma hayatında daha fazla yer alması ve giderek aile hayatındaki geleneksel rollerinden uzaklaşması, erkekleri iş hayatında başarılı olma görevinin yanı sıra, aile yaşamını da başarılı biçimde yürütme görevini üstlenmek zorunda bırakmıştır (Akça ve Tönel 2011, s.3).

Kasap karakterini, kızını bebeklikten itibaren yalnız büyüten, aynı zamanda kasap dükkânında zor bir işte çalışan, yalnız bir baba olarak düşünebiliriz. Kasap, hızlıca verilen görüntülerde bir yandan dükkanda kocaman kemikleri keserken bir yandan da kızının bakımını tek başına üstlenir; saçını tarar, oyun oynar, banyo yaptırır. Ama Atlas Sendromu tanısı kasabın içinde bulunduğu duruma pek uygun düşmez. Çünkü onun iş hayatının yanında aile hayatında da bazı roller üstlenmesi mükemmellik arayışından kaynaklanmaz, aksine kasabınki zorunlu bir seçimdir; sevgilisi, onu ve kızını terk ettiğinde iki rolü de üstlenmek zorunda kalır. Yine de kasabın yalnız bir baba olarak içinde bulunduğu psikolojik durum Atlas Sendromunun sebepleri ve sonuçlarıyla ortak özellikler gösterir.

Fransa' daki yalnız ebeveynler üzerine yapılan çalışmada, yalnız babaların çocuk yetiştirme konusunda zorunlu olarak çoğu evli babalardan daha ilgili olduğu ve yalnız babaların davranışlarıyla çocuklarının beklentileri arasında önemli bir ilişki olduğu sonucu ortaya çıkmıştır (Miljkovitch, Danet ve Bernier 2012, s.786). Carne' nin ilk bölümündeki kasap ile kızı arasındaki ilişki de kısmen böyledir. Ama bu görüntü aldatıcıdır; çünkü ortada hasarlı bir iletişim vardır, babanın kızına olan ilgisinin aksine küçük kızın tek iletişim kaynağı büyük bir tutkuyla izlediği televizyondur. ${ }^{6}$ Sonuç olarak kasap, bu iletişimsizliğin ya da bir anne figürü eksikliğinin bedelini hapse girerek öder; küçük kız ilk defa adet kanaması geçirdiğinde korkuyla dışarı çıkar, çevredekiler onu bir işçiyle görüp kızı babasına getirir, kasap kızın eteğindeki kanı görüp kızına tecavüz edildiğini düşünür ve dışarı çıkıp bir işçiyi bıçaklar. Bu

6 Küçük kızın dilsiz oluşu da bu iletişimsizliğin etkenlerinden biridir. 
sahne, kasabın üstlendiği iki rolün de o an iflas ettiğini gösterir. Kasap, hayatında bir kadının eksikliğini hissettiğini ise filmin sonlarına doğru kendi sözleriyle ifade eder: "Fakat ben ne istesem asla olmadı. Anne yok, eş yok."

Ama filmde gerçek bir mağdur varsa o da şüphesiz kasabın küçük kızıdır. Küçük kız hayranlıkla izlediği televizyon dışında kimseyle iletişim kurmaz, çevresindeki hiçbir olaya tepki vermeden, pasif bir konumda hayatına devam eder. En kötüsü ise o büyüdükçe bedenine farklı gözle bakmaya başlayan bir babayla tek başına, sessiz bir hayat sürmek zorunda kalmasıdır.

\section{Kasaplık mesleğinin arkasındaki anlamlar}

Filmin hemen başında, mezbahada tüm güzelliğiyle ölümü bekleyen kahverengi bir atın, Haneke'nin Benny's Video (Benny'nin Videosu, 1992) filminden aşina olduğumuz hayvan tabancasıyla vurularak öldürülmesinden hemen önce ekranda şu uyarı belirir: "Dikkat, Bu film şok edici görüntüler ve kaba bir dil içerir." Film boyunca bunun gibi çeşitli bilgiler ve uyarılar veren, Godard'ı hatırlatan büyük puntolu yazılara bir de şok edici uyarı sesi eşlik eder. At, vurulduktan hemen sonra kesilir, kafası gövdesinden ayrılır, derisi yüzülür. Ardından yine aynı tarzda bir ara bilgiyle "Birkaç gün sonra" yazısı ekrana gelir; beyaz tabaktaki pişmiş at eti çatal ve bıçakla kesilir.

Sinema tarihinde birçok film kasaplık mesleğini, kanlı şiddeti ve korkuyu simgelemek için kullanmıştır. ${ }^{7}$ Kasap, sadece filmlerde değil, medyada ve yazılı eserlerde insanları öldüren bir katil, karanlık dünyası olan bir adam ya da öldürücü yeteneklere sahip bir asker olarak sıkça kullanılan bir figürdür. İçinde kasapların yer aldığı filmlere bakıldığında ise genelde korku ve aksiyon filmleri öne çıkar, bu filmlerde kasap, elindeki satırla masum insanları tehdit eden bir canavar gibi gösterilir. ${ }^{8}$

Kasap karakterinin, üstüne kan sıçramış bir katil figürü olarak öne çıkmasının nedeni kasaplık mesleğinin doğasından kaynaklanır. Kasaplar ellerin-

7 Bunlardan bazıları: Andre the Butcher (Kasap Andre, Philip Cruz, 2005), The Butcher, the Chef and the Swordsman (Kasap, Şef ve Savaşşı, Wuershan, 2010), Blood: A Butcher's Tale (Kan: Bir Kasap Masall, Mark Tuit, 2010), The Butcher (Kasap, Edward Gorsuch, 2006), The Butcher (Kasap, Jesse V. Johnson, 2009).

8 Kasap Andre filminin afişinde elinde satır, üzerinde kanlar içinde bir önlük bulunan kasap, objektife tehdit edici bir tavırla bakar. Kan: Bir Kasap Masalı filminin afişi ise neredeyse aynıdır. İri yapılı erkek karakterin elinde yine bir satır, üstünde ise kanlı bir önlük vardır, karakterin diğer elinde ise bir kafatası vardır. İki fotoğraf da alt açıdan çekilerek karakterleri dev bir canavar gibi gösterir. 
deki büyük satırlarla koca koca etleri, kemikleri parçalarken ya da mezbahada hayvanları canlı canlı keserken adeta bir katil gibidirler. Üzerlerindeki beyaz önlüğün kana bulanması da işlerinin bir parçasıdır. Kasaplık mesleği bu özellikleriyle ele alındığında fazlasıyla maço bir meslek olarak karşımıza çıkar. Parry, hayvan öldürmenin Batı toplumlarında maçoluğu koruyan bir davranış olduğunu, avcıların büyük bir kısmının erkek olduğunu ve avcılık hakkındaki yazıların çoğunun cinsel (heteroseksüel) terimlerle ifade edildiğini belirtir (Parry 2010, s.385). Cudworth ise kasaplarla yaptığı görüşmelerin ışığında, kasaplık mesleğinin düşük statüsüne rağmen hayvan öldürmenin ve parçalamanın maçoluğun artırılması anlamına geldiği sonucuna ulaşır. Ayrıca çalışmasındaki bir röportaja göre, genç erkekler kasaplık mesleğini maço özellikleri yüzünden çekici bulurlar ve bu mesleği seçerler (Cudworth 2008, s.41).

Kasaplık mesleğinin maço yanı sıklıkla sinema temsillerine de yansıtılmıştır. Özellikle Yeşilçam melodramlarında kasapları sert, tutucu ve maço aile babaları olarak görmemiz mümkündür. Bu melodramlardaki kasapların bir diğer ortak özellikleri de erkeklik onurlarını sarsacak bir durum olduğunda (özellikle namus konusunda) elindeki büyük et bıçağıyla cinayet işlemek için dükkanlarından hızla çıkmalarıdır. Carne’deki kasap da henüz ergenlik çağında olan kızının elbisesindeki kanı görünce, tezgahın üzerindeki bıçağı alıp kızına tecavüz eden kişiye saldırmak üzere hızla dükkandan ayrılır. Kasabın o an içinde bulunduğu durum bir melodramı andırır. Bir melodram gibidir, çünkü kızına tecavüz edilmemiştir, kızı ilk kez adet kanaması geçirmiştir; kan lekesi o yüzdendir. Ayrıca yanlış işçiyi bıçaklamıştır, kızını ıssız bir yere götürüp öpmeye çalışan aslında başka bir işçidir. Ama bu sahneler melodram olmak için fazla hızlıdır, seri kamera hareketleri ve bu kamera hareketlerine eşlik eden uyarı sesleri melodram havasını iyice bozar.

Kasapların etleri kesmek için kullandığı bıçak, medyada sıklıkla bir cinayet silahı olarak gösterilir. Birçok cinayet haberi katilin cinayeti "kasap b1çağıyla" işlediğini anlatan başlıkla verilir. ${ }^{9}$ Bunların dışında yine medyada kasaplığa atıfta bulunulan tartışmalara da sıkça rastlanır. Özellikle siyasetçiler

9 TRT Haber sitesinden yayınlanan görüntülü haberin başlığı şöyledir: "Polise Kasap Bıçağıyla Böyle Saldırdı". Bkz. http:/ / www.trthaber.com/haber/dunya/polise-kasap-bicagiyla-boyle-saldirdi-52245.html [Erişim tarihi: 11 Şubat 2014]. Zaman gazetesinin internet sitesinde "Katil, Bayram Ali Hoca'yı Kasap Bıçağıyla Öldürmüş" başlığı altında bir haber yer alır. Bkz. http:/ / www.zaman.com.tr/newsDetail getNewsById.action?newsId=497557. [Erişim tarihi: 11 Şubat 2014]. 
birbirlerini suçlamak için kasap kelimesini çok sık kullanırlar. ${ }^{10}$ Ayrıca kasap kelimesi, bazı askeri figürler için, yapılan katliamların şiddetini ve sayısını niteleyen bir lakap olarak da kullanılır; Bosna Kasabı Ratko Mladić, Etiyopya Kasabı Rodolfo Graziani gibi. ${ }^{11}$

İster gerçek ister film karakteri olsun verilen bütün örneklerde kasapların erkek olması tesadüf değil, kasaplık mesleğinin erkek-egemen statüsünün bir sonucudur. Birçok erkek, hayvan öldürmeyi, derisini yüzüp etlerini parçalamayı erkeksi bir uğraş olarak görürken, kadınların, hayvan bedenleri üzerindeki insan hakimiyetine karşı hassasiyeti ise erkeklerden farklıdır. Her ne kadar birçok kadın et tüketiminin parçası da olsa eti tüketim malzemesi haline getirenler erkeklerdir. Luke, bir kadının biftek satın aldığında, aslında bir erkeğin bir hayvanı öldürmesi sonucunda ortaya çıktığı düşünülen bir ürün satın aldığını belirtir. Eğer kadın daha sonra bu bifteği geleneksel olarak yapılandırılmış ailesi için pişirse, erkek şiddetinin bir sonucu olarak ortaya çıkan bir ürünün bir erkek tarafından tüketilmesine yardımcı olmuş olur (Luke 2007, s.16). Öte yandan Adams'a göre, hayvanların kesimi, et yenilmesini mümkün kılan eylemin kendisidir. Hayvanlar kesim aracılığıyla kayıp göndergelere dönüşür. Hayvanların varoluşu ete indirgendikçe isimleri ve cisimleri ortadan kaybolur. Adams, hayvanların nasıl kayıp göndergelere dönüştüğünü ise dil üzerinden açıklar. Buna göre hayvanlar, tüketiciler onların ölü bedenlerini yemeden önce dil tarafından yok edilir ve "et" denildiğinde aklımıza kesilmiş, öldürülmüş hayvanlar değil mutfak gelir (Adams 2013, s. 99-100).

Kasapların yıllarca hayvanların etlerini, kemiklerini kesip, iç organlarını ayıkladıkları, her gün ellerini hayvan kanına buladıkları düşünüldüğünde,

10 www.ntvmsnbc.com'da "Erdoğan'dan MHP'ye: Kasap mısınız?" başlığı altında, "Başbakan Erdoğan, MHP’nin kendisine yönelik söylemine sert çıtı. 'Dilini koparacağız' sözüne yanit veren Erdoğan, 'Siz kasap misınız?' dedi.” şeklinde bir haber yer alır. Bkz. http://www. ntvmsnbc.com/id/25149566 [Erişim tarihi: 11 Şubat 2014].

11 Birgün gazetesinde verilen bir haberde “'Kasap' lakaplı Kızıl Kmer komutanı öldü” başlı̆̆1 altında, Kamboçya' da yüzbinlerce kişinin ölümünden sorumlu tutulan Kızıl Kmerlerin eski komutanlarından “kasap” lakaplı Ta Mok'un öldüğü haberi verilir. Bkz. http:/ / www.birgun. net $/$ world index.php?news code $=1153525728 \&$ year $=2006 \&$ month $=07 \&$ day $=22$ [Erişim tarihi: 11 Șubat 2014].

Bir diğer haberde "Kaddafi'nin 'kasap' lakaplı adamı Sennusi yakalandı" başlığı kullanılır. Bkz. http://t24.com.tr/haber/kaddafinin-kasap-lakapli-adami-sennusi-yakalandi/199602. [Erişim tarihi: 11 Şubat 2014].

“'Kasap' lakaplı Taliban gözaltında öldü" başlı̆̆ı altında başka bir haber de ntvmsbc.com'da yer alır. Bkz. http:// www.ntvmsnbc.com/id/25002201 [Erişim tarihi: 11 Şubat 2014]. 
hayvan bedenleri üzerinde uzun mesailer harcamanın bu mesleği yapanlar üzerinde psikolojik sorunlara neden olması öngörülebilir bir sonuçtur. Mezbahalarda ve perakende et sektöründe çalışan kasaplar üzerine yapılan bir araştırmada, mezbaha işçilerinin sürekli hayvan öldürmelerinden dolayı kayg1, panik, artan paranoya, dağılma duygusu gibi rahatsızlıklardan acı çektikleri belirlenmiş ve yüksek düzeyde ilaç ve alkol kullanımı da sık rastlanan durumlar olarak belirtilmiş. Anket yöntemiyle yapılan araştırma sonucunda, depresyon, kaygı, sinir bozukluğu, paranoya ve diğer psikolojik rahatsızlıkların oranının kasaplardan seçilen grupta, sıradan mesleklerden seçilen kontrol grubundakilerden daha fazla olduğu saptanmıştır (Emhan, Yıldız, Bez ve Kıngır, 2012). Belki de Carne' deki kasabın hayata bakışındaki nihilist hava bunun gibi psikolojik etkenlerin bir sonucudur.

\section{Bir erkeklik deposu: "et"}

Et en çok nerede tüketilirse, en büyük cinsiyet adaletsizliği de orada olmalıdır. (Rothgerber 2012, s.3).

"Carne", Fransizcada et, etli, at eti, sert et gibi anlamlara gelmektedir. Filmde et, hem filmin kendisi için hem de kasap için önemli simgeleri içerir. Kasap için et, işleyip sattığı ve ondan geçimini sağladığı bir mal, güçlenmek, kanlı canlı olmak için tükettiği bir besin ve hem kendisi hem de kızı için kullandığı bir tanımdır. ${ }^{12}$ Herkese Karşı Tek Başına filminde ise et, kasabın sadece kızı için değil, diğer tüm insanlar için kullandığı bir ifadedir. ${ }^{13}$ Kasabın bir nihilist olarak görülmesinin en büyük nedenlerinden biri kasaplik mesleğinden miras kalan bütün canlıları sadece bir et parçası olarak görme anlayışında saklıdır. Adams, özellikle tecavüze uğrayan ve dayak yiyen kadınların kullandığı "Kendimi bir et parçası gibi hissettim." cümlesindeki gibi metaforların hayvanların kayıp göndergelere dönüşmesinde, yani onların yok sayılmasında bir yöntem olarak kullanıldığına dikkat çeker. Etin anlamı metafordan çıkarıldığında gerçek ortaya çıkar: Hiç kimse bir et parçası olmayı deneyimleyemez. Et metaforunda, hayvanların kaderi insan merkezli bir hiyerarşinin içine

12 Kasabın filmin başlarında, kızının vücuduna bakarak söylediği “...ve kadın olacak, benim etimle, benim kanımla" cümlesi ya da filmin sonlarındaki "Kızımı sevdim. O benim etim, o benim kanım" ifadesi onun bu bakış açısının kelimelere döküldüğü nadir anlardır.

13 Karnını yumrukladığı hamile sevgilisi acılar içinde "Bebeğim" diye ağlarken, kasap, "Ne bebeği, bebeğin bir parça köfteden başka bir şey değil. Et" der. Ya da tüm insanlar için bir eleştiride bulunup "Etten, kemikten ve yağdan ibaret olduğumuzu herkes unutuyor." der. Kızıyla otel odasındayken kurduğu fantezi sırasında ise "Ben çok fazla düşünen bir parça ettim.", "Kasap, kendi etini özgür bırak." gibi cümleler geçirir aklından. 
çekilmiştir (Adams 2013, s.100-101). Öte yandan hayvanlar için geçerli olduğu gibi kadınlar için de kayıp gönderge sistemi geçerlidir. Adams'a göre ataerkil değerler kayıp gönderge aracılığıyla kurumsallaşır. Etten bahsederken kullandığımız dilde cesetlerin olmaması gibi, kültürel şiddetin açıklamalarında da çoğunlukla kadınlar kayıp göndergelerdir. "Dünyaya tecavüz edilmesi" gibi metaforlarla kadınların deneyimi başka baskıları açıklamak için araç haline gelir (Adams 2013, s.102).

Kasabın et ve insanlar üzerine ne düşündüğünden bahsettikten sonra, bu konuda araştırma yapanların ne düşündüklerine değinmek gerekir. Sobal, yiyeceklerin etnisite, milliyet, bölge, sınıf, yaş, cinsiyet, kültür ve hepsinden önemlisi toplumsal cinsiyet gibi birçok anlamı içinde barındırdığını belirtir (Sobal 2005, s.136). ABD'de ve birçok Batı toplumunda eril anlam yüklenmiş biftek, hamburger, patates ve birayı içeren yiyecekler erkek yiyecekleri olarak düşünülürken, kadınların yiyecekleri ise salata, makarna, yoğurt, meyve ve çikolata gibi kadınsı anlam yüklenmiş yiyecekler olarak görülür (aktaran Sobal, 2005, s.137). Potts ve Parry'e göre, Batı kültürlerinde et yeme ve erkeklik arasında yerleşik bir bağ vardır. Et tüketimi, normatif erkekliklerin sergilenmesinde merkezi konumdadır, ayrıca et, sağlıklı erkek bedeni için zorunlu bir besin maddesi olarak görülür (Potts ve Parry 2010, s.58). Adams, ataerkil kültürün mitlerine göre etin gücü artırdığını, erkeklik özelliklerinin erkeksi yiyecekler yiyerek elde edildiğini belirtir. Öte yandan erkeklerin et yiyememesinin erkeksi olmadıklarının ilanı olarak görülmesine, et yemekten imtina etmeye karar veren erkeklerin kadınsı sayılmasına yol açtı̆̆ını söyler (Adams 2013, s.87-89). Erkeklik ve et yeme arasındaki bu bağlantılar tarih boyunca, özellikle de geleneksel erkeklik tehdit edildiğinde belirgin bir rol oynamıştır. Rogers, 2006 ve 2007'de, televizyon izleyicisine erkeklikle ilgili et odaklı bir dizi reklam sunulduğunu, Burger King ${ }^{14}$ ve diğer şirketlerin kırmızı eti cinsiyetleştirme konusunda önemli rol oynadığını belirtir. Ayrıca blog yazarlarının bu reklamların anti-feminist, anti-vejetaryen ve anti-çevreci mesajlarına dikkat çektiğini söyler. Bu reklamlarda et yemek basit bir erkeksi aktivite olarak

14 Burger King'in 2006'daki "Manthem" reklamının incelendiği bölümde, reklamın eti ve erkekliği Helen Reddy'nin 1972'deki I Am Woman (Ben Kadınım) isimli feminist marşının parodisini yaparak övdüğünü söyler. Reklamda beyaz masa örtüleriyle dolu, minimal dizaynla dekore edilmiş, şık bir restoranda karşılıklı oturan genç çifte servis yapılır. Tabağın içinde iyi süslenmiş, oldukça küçük ve az soslu bir yemek vardır. Tabağı gören erkek hayal kırıklığıyla ayağa kalkar ve "I Am Man..."(Ben erkeğim) diye başlayan şarkıyı söylemeye başlar, elindeki peçeteyi fırlatır ve restorandan dışarı çıkar. Daha sonra Burger King'e gidip bir hamburger alır. (Rogers 2008, s.293-294). 
değil, hegemonik erkekliğin devam eden hakimiyetinin tehdit edilmesi karşısında yeniden onarımının gerekliliği anlamında kodlanmıştır. Bu reklamlar erkeklik krizine ve bu krizin karşısında bir tehdit olarak duran feminizme işaret ederler (Rogers 2008, s.281-282).

Filmde kadın-erkek kimlikleri üzerinde et tüketiminin rolünü gözler önüne serecek sahneler oldukça fazladır. Filmin başında, at eti üzerine verilen uzun bilgiler erkeklerin et tüketimi konusundaki en önemli gerekçesini içerir: "At eti bilinen en lezzetli ettir, ayrıca çok da sağlıklıdır". Filmde kasabın onu terk eden sevgilisi, tabaktaki etten bir lokma aldığında kasap, "Yemelisin, hamilesin ve güçlü olmasın" diyerek onu et yemeye teşvik eder. Kasabın k1zıyla yemek masasındaki sahnesi ise cinsiyet ve et yeme eğilimi arasındaki farkı daha net ortaya koyar. Kasap iki parça etin birini kendi tabağına, diğerini kızının tabağına koyduktan sonra kendi tabağındaki eti yemeye başlar, ama kızı önündeki tabağa hiç dokunmaz, karşısındaki televizyonu seyreder. Kasap, kızına "Neden yemek yemiyorsun? Güçlü olmalısın" der. Küçük kız önündeki ete dokunmamakta ısrar edince babası onun tabağından bir parça et kesip zorla kızına yedirir ve uzun bir süre önündeki eti yemesi için ısrar eder. Kasabın et yemek ve güçlü olmak arasında kurduğu ilişki sadece ona özgü bir düşünce değildir, birçok toplumda et, gücün ve sağlıklı bir bedenin kaynağ olarak görülür. Adams'a göre iktidar sahibi insanlar hep et yemişlerdir. İşçi sınıfı karbonhidratlardan oluşan bir karışımı tüketirken, Avrupa aristokrasisi her çeşit etle dolu büyük öğünler yemiştir (Adams 2013, s.76). Filmdeki son et yeme sahnesinde ise et yeme ve iktidar arasındaki bu ilişki gözler önüne serilir. Kameranın önünde kasabın hapisten çıtıktan sonra sevgilisi olan kadın yer alır. Kadın önündeki etten bir parça alıp yemeye başlar, ağzı etle doluyken bir yandan da ağzını şapırdatarak konuşmaya devam eder. Önceki örneklerde et yeme konusunda isteksiz olanlar kadınların aksine bu sahnede eti zevkle yiyen kişi bir kadındır. Aslında bu durum kadının fiziksel özellikleriyle de örtüşür; kadın şişman ve iri yapılıdır, bu da et ve güçlü beden arasındaki ilişkiyi pekiştirir. Öte yandan kadının kasap karşısındaki otoriter konumu, et yeme hakkının kasaptan alınıp kadına verildiğinin göstergesidir. Kadın, eril bir donanıma sahip, güçlü bir kadın olarak yemek masasının hakimi konumundadır.

Küçük kızın tabağındaki eti yemeyi reddetmesi feminizm açısından sembolik bir anlam taşır. Sobal'ın da belirttiği gibi, et yememek feminen bir davranış olarak düşünülürken, feminizmin erkek hegemonyasına karşı yemek kültürü içinde gerçekleştirdiği bir eylemdir. Vejetaryenlik de et yememenin en son noktasını temsil eder, et tüketen erkekliğin desteklenmesinin 
karşısında negatif bir tutum sağlar (Sobal 2005, s.140). Rothgerber, et tüketiminin gerekçeleri üzerine yaptığı çalışmasında, erkeklerin et yeme konusuna daha olumlu anlamlar atfettiklerini, hayvanların acı çektiğini reddettiklerini, hayvanların hiyerarşik düzende insanlardan daha alt düzeyde olduklarını, et tüketimi konusunda dini sebepleri ve sağlık gerekçelerini ön planda tuttuklarını belirtir. Diğer taraftan kadınların ise hayvanları sadece tabaklarında kendilerine sunulan bir yemek olarak görmekten kaçındıklarını ve hayvanların acı çektiğinin farkında olup hayvan hakları konusunda daha duyarlı bir eğilim gösterdiklerini söyler (Rothgerber 2012, s.4). Kadınların ve erkeklerin et yeme konusundaki farklı eğilimleri, Merriman'ın vejetaryen diyet uygulayan kişiler üzerinde yaptığı çalışmasında da kendini gösterir. Buna göre babalar

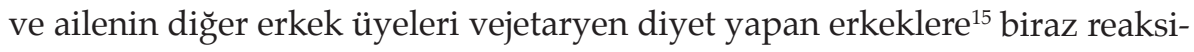
yon gösterip negatif yorumlar yaparken anneler ise diğer vejetaryen arkadaşlar gibi olumlu tepkiler verir ve diyetin oğullarının sağlığına iyi geleceğini, oğullarının olgunluğunu yansıttığını düşünürler (Merriman 2010, s.422).

Et tüketiminin erkek kimliği üzerindeki etkisinin yanında etin nasıl servis edildiği de bu etkinin güçlendirilmesi açısından önemlidir. Sobal, etin az pişirilerek, asgari düzeyde servis edilerek ya da az bir sosla direkt yenmesinin, eti kadınsılıktan ve uygarlıktan kaçınmak için daha fazla erkekleştirdiğini belirtir (Sobal 2005, s.138). Steve Rose'un, filmin yönetmeni Gaspar Noé hakkında yazdığı makalenin ilk satırları ise yönetmenin yemek seçimi ile filmlerindeki sarsıcı atmosfer arasındaki ilişkiye işaret eder:

Gaspar Noé yorgun ve aç. Londra'da, bir restoranda sıcak bir öğleden sonra. Patates kızartmasız, kenarında sos olan bir biftek sipariş ediyor. Sosa dokunmuyor. Öğle yemeği sadece bir parça et. Bu, nedense tam da Noé'den bekleyeceğiniz bir şey. Onun filmleri yüzünüze bir tokat gibi çarpıyor ve güçlü bir mide gerektiriyor. 40 dakikalık filmi Carne'nin ilk sahnesi öldürülen ve kesilen bir atı gösterir. İkincisi ise tabaktaki bir bifteği, tıpkı şimdi Noé’nin önünde duran gibi..."Ahlâk sahibi olmadan önce, insanlar çoğunlukla, hakimiyet kurmak için ve hayatta kalmak için savaşan hayvanlardı." diyor ağız dolusu biftekle (Rose, 2010).

15 www.ntvmsnbc.com' daki "Et yemeyen erkek değildir" başlıklı haberde ABD' de yapılan bir araştırmanın sonucuna göre erkeklerin vejetaryen beslenmemesinin nedeni olarak bu beslenme şeklinin "yeteri kadar maço olmaması" şeklinde bir saptamadan bahsedilir. Haberin sonunda ise şu ifadeler yer alır: "Araştırmaya katılanlara yiyecekler üzerindeki metaforlar soruldu. Sonuçta 'etin sebzeye göre daha erkeksi bir yiyecek olarak kabul edildiği' ortaya çıktı." Bkz. http://www.ntvmsnbc.com/id/25351216 [Erişim tarihi: 11 Şubat 2014]. 


\section{Herkese karșı tek bașına (1998)}

Noé'nin, Carne'den yedi yıl sonra çektiği ilk uzun metrajlı filminde neden aynı hikayeyi devam ettirdiği sorusunu bir yana bırakırsak, Carne'nin devam filmini neden bu kadar geç çektiğini anlamak için finansal süreçte yaşadığı zorlukları dikkate almakta yarar var. Yönetmenin devam filmini çekmesi hiç de kolay olmadı, ilk filmini yeterince şiddet dolu bulan yapımcılar daha şiddetli bir filmi uzun metrajlı bir projede desteklemeye yanaşmadılar, zaten eleştirmenler de filmi Fransız sinemasının dışında tuttular. Noé'nin filmi sadece ana akım Fransız sinemasının karşısında değil bütün Fransız sinemasının karşısındaydı, hatta kendisinin de parçası olduğu festival odaklı sinemanın bile. Noé, filminin anti-Fransız bir film olduğunu söyler ve fazla muhafazakar bulduğu Fransız sinema endüstrisini altı insanın hangi filmin yapılıp hangi filmin yapılmayacağına karar verdiği özel bir kulübe benzetir (Bailey, 2003).

Holden (1998), filmin Godard'in dokunuşu ile Dostoyevski'in süzge-

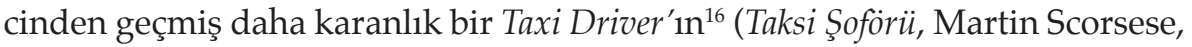
1976) devam filmini temsil ettiğini belirtir. Noé ise Straw Dogs (Saman Köpekler, Sam Peckinpah, 1971) filminden ilham aldığını, filmdeki tecavüz sahnesinin çok güçlü olduğunu söyler ve sadece o zaman bir sinema salonundan çıkıp gittiğini, çünkü çok korktuğunu belirtir (Judell, 1998). Irreversible (Dönüş Yok, Gasper Noé, 2002) filmi Cannes Film Festivali'inde gösterildiğinde ise bu sefer kendisi aynı tepkiyle karşılaşır. Monica Belluci'nin yaklaşık 10 dakika boyunca tecavüze ve fiziksel şiddete uğradığı sahnesinden dolayı, birçok izleyici filmin ortasında sinema salonunu terk edip, Noé'ye ateş püskürür.

İlk bölümde Carne filmi altında ele alınan yalnız baba, kasaplık ve et temaları Herkese Karşı Tek Başına filmi için de geçerlidir. Noé, ilk filmin ekibini ve hikâyesini bozmayarak ikinci filmde de aynı atmosferi yakalamış, hatta o atmosferi bir adım ileri götürüp uluslararası alana tanıtmıştır. Herkese Karşı Tek Başına'da eskilerin yanında yeni temalar ön plana çıkar. Öncelikle, kasap artık yalnız bir baba değildir, çünkü kızı o hapisteyken yetiştirme yurduna verilmiştir, hapisten çıktıktan sonra ne kasap dükkanı ne de bir evi vardır. Ka-

16 Herkese Karşı Tek Başına filminde kasap (Philippe Nahon) otel odasında, elinde silahla aynaya bakarak barda tartıştığı adamlara ateş ettiğini hayal eder. Bu sahne Taksi Şoförü'nde, Travis'in (Robert De Niro) elinde silahıyla karşısındaki boy aynasına bakarak yaptığı o meşhur konuşmaya üstü kapalı bir göndermeyi içerir, tıpkı La Haine (Protesto, Mathieu Kassovitz, 1995) filminde Vinz'in (Vincent Cassel) ayna karşısındaki performansı gibi. Ama kasap ne Travis gibi ne de Vinz gibi kendi kendine konuşur, sadece aynadaki yansımasına silahı doğrultur ve film boyunca yaptığı gibi tüm konuşmaları aklından geçirir. 
sap artık sevgilisinin parasına muhtaç bir adamdır ama sevgilisiyle zorunlu yürüttüğü bu ilişki de kısa sürer. Dolayısıyla artık yalnız bir baba değil, yalnız bir erkektir. Kasaplık ise hâlâ geçerlidir, tek farkı işsiz bir kasap oluşudur. İç konuşmalarında bile kendi ismini söylemez, onun yerine kendine kasap diye hitap eder. Son olarak et teması da bu filmde önemli yer tutar ama belirgin bir anlam farklılığı vardır. Kasap ilk filmde hem dükkanında hem de tabağında bolca gördüğü etlerle mutluyken ikinci filmde et, sadece rüyalarına giren bir arzu nesnesidir. Kasabın sevgilisi ve annesiyle yemek masasında oturduğu sahne onun sarsılan erkekliğine dair çok şey anlatır. Sevgilisi ve yaşlı kadın masada duran sucuktan bir dilim alıp yerken, kasap elini çenesine koymuş televizyon izler ${ }^{17}$, tıpkı Carne' deki yemek sahnesinde, kızının önündeki eti yemeyip televizyon izlemesi gibi. Eril bir simge olan et yeme eylemi artık bu iki kadının ellerindedir.

\section{Eril suskunluk ya da dișil sessizlik}

Toplumsal cinsiyet çalışmalarında kadınların sessizliği üzerine birçok anlam yüklenmiştir. Erkeklerin aile ortamındaki suskunluğu ise bu konu dahilinde ele alınan sorunlardan biri olmuştur. Polat, erkeğin kamusal alanlardaki hakimiyetinin bir çok kültürde sadece erkeklere özgü vakit geçirme mekanlarının oluşmasına neden olduğunu ve bu mekanların erkeklere erkekler arasında sosyalizasyon imkanı sunduğunu belirtir. Bu mekanlara sadece erkeklerin girebildiği kadınların alınmadığı yerler olan kahveleri örnek olarak verir (Polat 2008, s.147). Erkeklerin, homososyal iletişime imkan veren bu mekanlarda kendilerini ifade etmelerinin bir sonucu olarak aile içinde, kadınlara karşı bir suskunluk durumu ortaya çıkar. Evdeki erkek annesiyle, karısıyla, kızıyla konuşmak istemez, küçük erkek çocuk ailedeki yetişkin kadınları ciddiye almaz, bunun yerine daha ciddi konuları erkek aile bireyleriyle konuşmayı tercih eder. Erkeklerin kadınlar karşısındaki suskunluğunun altındaki asıl düşünce, kadınların, erkeklerin konuşmak isteyeceği alanlarda fikir sahibi olamayacağı görüşüdür. Doğal olarak bu erkekler, konuşma haklarını, önemli meseleler hakkında fikir sahibi olduklarını düşündükleri diğer erkeklerle birlikteyken kullanırlar.

Filmde kasap, sevgilisi ve onun annesiyle yaşarken onlarla neredeyse hiç konuşmaz, onun yerine film boyunca yaptığı gibi kafasından bir oda do-

17 Kasap bu sahnede et kesilirken aklından şu cümleleri geçirir: "Lanet sucuk, lanet şarap. Sıkıcı bir şehirde lanet aile." Kasabın daha önceleri etle arasında kurduğu iyi ilişki bu cümlelerle bozulmuştur. 
lusu düşünce geçirir. Filmin başlarında kasabın sevgilisi gülümseyerek " $\mathrm{O}$ tarafta genelde babam uyurdu" der, ama kasap hiçbir tepki vermeden kafasında cümleler kurmaya başlar: "Böyle konuşmaya devam ederse kafasını keseceğim". Sevgilisi ve annesiyle yemek yediği sahnede yaşlı kadın ona ailesi hayatta mı diye sorduğunda kasabın ağzından tek bir kelime bile çıkmaz, kafasını hafif̧ce televizyondan çekip yaşlı kadına döndürür ve küçümsercesine bir bakış atar. Kafasının içindeki düşüncelerin yüksek sesle dışarı çıktığı sahne ise sevgilisinin karnını yumrukladıktan sonra, yaşlı kadını evdeki silahın nerde olduğunu söyletmeye zorladığı sahnedir. Bu sahnelerde avazı çıktığı kadar bağırır, hakaret eder.

Erkeğin bilinçli suskunluğunun karşısında doğal olarak kadının zorunlu sessizliği ortaya çıkar. Sessizlik, zaten kamusal alanda söz hakkına sahip olmayan kadının, evde erkeğin onunla konuşmayı tercih etmemesinden dolayı kaderi haline gelir. Öztürk ve Tutal'a göre, erkeklerin yanında kadınların, yetişkinlerin yanında çocukların sessiz kalması beklenir. Sessizlik aynı zamanda "söz" dinlemek, genellikle bir erdem olarak kodlanır. "Söz dinlemek" ifadesindeki kadından dinlenilmesi beklenen söz, eril sözdür. "Sessizlik"teki, kadının sahiplenmediği ses ya da yoksun bırakıldığı ses, erkeğin sesidir (Öztürk ve Tutal 2001, s.105). Kadınların sessiz kalmayı erkek-egemen dile karşı bir protesto olarak, bilinçli bir şekilde tercih ettiği durumlar sinemada, özellikle de kadınların söz sahibi olmadığı ya da daha az söz sahibi olduğu doğu toplumlarının filmlerinde sıkça kullanılan bir metafor olmuştur. Öztürk ve Tutal (2001), Zeki Ökten'in yönettiği Sürü (1978) filmindeki Berivan'ın, Yavuz Turgul'un yazıp yönettiği Eş̧kıa (1996) filminde sevmediği bir adamla evlendirilen Keje'nin, Piano (Piyano, Jane Campion, 1993) filminde sessizliğini etkin biçimde kullanan Ada'nın ve Persona'da (Ingmar Bergman, 1966) kendisine dayatılan anne ve eş kimliklerine direnmek için susan Elisabeth Vogler'in sessizliklerine dikkat çekerler. Sıkça kullanılan bir diğer metafor ise dilsiz kız çocuğudur. Herkese Karşı Tek Başına' da kasabın küçük kızı da konuşamaz, ama kızın sessizliği erkek hegemonyasına karşı bir tepki olarak yorumlanması için fazla naiftir. Çünkü küçük kız konuşmamanın ötesinde tek bir tepki bile vermez, babası ne derse onu yapar, nereye götürürse oraya gider.

Filmin biçimsel açıdan en etkili özelliği kasabın adeta bilincinin akıp gittiği iç monologlarında gizlidir. Kimi zaman on dakikayı aşan bu monologlarda ağzından tek kelime bile çıkmayan kasap, konudan konuya atlayıp, izleyiciyi adeta kendi bilinci içinde oradan oraya savurur. Tüm bu iç monologlar garip bir şekilde erkeğin suskunluğu hakkındaki paradoksu da gözler önüne 
serer. Birçok sanat filminde çok az konuşan, ağzını bıçak açmayan erkek kahramanların aksine, kasap çok konuşan bir geveze gibidir. Aslında ilk bakışta kasabın nerdeyse hiç konuşmadığını anlamak zordur. Biraz dikkatli izlendiğinde anlaşılır ki kasabın gerçek anlamda ağzından kelime çıktığı sahneler bir elin parmaklarını geçmez. Kasabın iç dünyasındaki monologlar atıldığında film de tamamen farklı bir film olur, sessiz bir sanat filmi halini alır. Daha da önemlisi bu monologlar olmadan kasabın sapkın görüşlerini anlamamız pek mümkün değildir. Bu özelliğiyle film bize, suskun kalmayı tercih eden erkeğin suskunluk mesaisinin sanıldığı kadar sessiz geçmediğini gösterir.

\section{İssiz bir kasabın, etsiz bir adamın șiddeti}

Riding (1999), Herkese Karşı Tek Başına filmini işsizlik, reddedilme ve sevgi eksikliğinden dolayı umutsuzluğa sürüklenmiş orta yaşlı bir adamın hikayesi olarak tanımlar. Bu kısa ve öz tanım, kasabın karanlık psikolojisini anlamak için bazı ipuçları verir. Kasap işsizdir ve işsizliğin bir sonucu olarak sevmediği bir kadınla yaşamak zorundadır, üstelik hiç istemediği halde kadından bebek bekler. Daha da önemlisi herkese nefret dolu gözlerle bakan kasabın "sevgi" duyduğu tek kişi olan kızı onun yanında değildir, çünkü ne kendine ne de kızına bakabilecek bir işi vardır. Her şeyi geride bırakıp belinde bir silah ve az miktarda parayla Paris'e döndüğünde ise reddedilme serüveni başlar. Eski arkadaşları ve eski müşterisi ona borç para vermez, işçi bulma kurumu, dükkân sahipleri onun iş talebini reddeder.

Noé, kendi filminin kahramanı için yaptığı yorumda, sokak köpeklerinin onlara bakacak kimseleri olmadığını, bu yüzden öldürüldüklerinde ya da başlarına herhangi bir şey geldiğinde kimsenin haberi olmadığını, sadece kaybolduklarını söyler ve Herkese Karşı Tek Başına' daki kasabın da kayıp bir köpek olduğunu belirtir (Sterritt 2007, s.310). Noé'nin sokak köpeği gözlemi çok yerindedir, çünkü kasabın başına bir şey gelmesi durumunda onu merak edecek kimsesi yoktur, hatta hamile sevgilisine öldürürcesine saldırdıktan sonra polis bile onu aramaz. Kızının yüzünde ise hep aynı ifade vardır, belki dilsiz oluşu bu ifadesizliğin sebebidir, ama babasıyla ya da babasız değişen bir şey yoktur, o da merak etmez kasabı. Kasap yalnızca borç para ve iş istediği sahnelerde kısa bir süre için fark edilir.

İşsizliğin erkek kimliği üzerinde yarattığı yıkıcı etki belki de ekonomik etkilerinden daha önemlidir. Filmdeki şok edici sahnelerden birinde kasap hamile sevgilisini, karnındaki bebeği düşürmek için öldüresiye döver. Bu vahşetin arka planında kasabın ekonomik olarak sevgilisine bağlı kalması ve 
ev içinde söz sahibi olmaması, bunun sonucunda da ekonomik olarak zarar gören erkek kimliğinin kurtarılması gerektiği inancı bulunmaktadır. Kasabın, Carne'de işçiyi bıçakladığı sahnedeki şiddetin sebebi namusu koruma gibi "güçlü" erkeklik halini temsil ederken, bu filmdeki şiddet sahnelerinin hepsi kasabın işsiz ve parasız oluşundan kaynaklanan "güçsüz" erkeklik durumlarına işaret eder.

Syzdek ve Addis (2010) eril normlara bağll1lğın işsiz erkekler üzerindeki olumsuz etkilerini araştırdıkları çalışmalarında, erkeklerin eril normlara göre sosyalleşmesinin işsiz kalmak gibi hayatlarında önemli bir olay meydana geldiği durumlarda, depresif etkileri fazlalaştırdığın belirtirler. Eril normlara bağlı kalmadaki başarı ise bazı toplumsal sınıflar arasında farklılık gösterir. DeKeseredy ve Schwartz, Amerika'daki etnik gruplara mensup genç erkeklerin eril kimliklerinin farklı sebeplerden dolayı reddedildiğini belirtir. Bu insanlar okullarda başarısız olurlar, iyi bir iş bulamazlar ve ırkçllğ̆a maruz kalırlar. Sonuç olarak bu gençler ekonomik ve sosyal problemler sonucunda kaybettikleri erkeklik statüsünü ve saygıyı çeteler içinde kazanmaya çalışırlar (DeKeseredy ve Schwartz 2005, s.361). Filmin ilk sahnesi de bu görüşü destekler niteliktedir. Siyah ekranda büyük puntoyla, beyaz renkte "AHLAK" yazar, sonra erkeklerle dolu bir barda deri ceketli adam, karşısındaki takım elbiseli adama, ahlakın ona sahip olana, yani zengine ait olduğunu söyler. Daha sonra ekran kararır, bu sefer "Adalet" yazısı görünür. Ardından deri ceketli adam "Size benim ahlakımı göstereyim mi?" dedikten sonra belinden bir silah çıkarıp "Bu benim ahlakım" der. Karşısındaki adamı silahla göstererek "Üniformalı bay ahlak her zaman kazanır" dedikten sonra silahı kastederek "Bu benim adaletim" der.

Filmdeki en dehşet verici sahneden önce siyah ekranda şöyle bir bilgi verilir: "Dikkat! Filmdeki görüntülerden uzaklaşmanız için 30 saniyeniz var", ardından saniyeler 30'dan geriye doğru gitmeye başlar. Sonraki sahneler gerçekten de dehşet vericidir; genç kızın, babası tarafından vurulduktan sonra boynundan uzunca bir süre kanlar akması, Carrne'de, atın boynunun kesilmesinden sonra akan kanları hatırlatır. Bu görüntülerin ve kasabın kızıyla ilişkiye girdiği sahnelerin hayal olması bir teselli olabilir ama yine de kızın kanlar içinde can çekişmesi izleyiciyi fazlasıyla dehşete düşürür. Noé, filmdeki şiddet görüntülerini kimsenin gereksiz bulmadığını, tüm yaptığının hayatın pozitif yanların filtreleyip, kasabı varoluşunun negatif gücüyle baş başa bıraktığını söyler (Riding, 1999). Graham ise film için "zavallı bir ruhun portesi" yorumunu yapar ama filmin uyarıcı bir yanı olduğunu da ekler. Ona göre 
kasap, bir canavar olarak gösterilmez, bir sürünme hikâyesi değildir onunkisi. Kasabın hikâyesi günlük gazetelerdeki suç sayfaları haberlerinde bulunan cinsten bir hikâyedir (Graham, 1999). Son söz ise yönetmene ait, Noé’ye göre filmi izleyen birçok insan siyah yanları görüp içindeki mizahı görmez. Her şey izleyenin hayata bakış açısıyla ilgilidir. Eğer filmdekiler hayata bakış açımıza çok yakınsa mizahı göremeyiz. Ama hayata bakış açımızdan çok uzaktaysa mizahı görebiliriz. Bazen depresif karakterli insanların filme iyi tepkiler vermediğini belirterek sözlerine son verir (Judell, 1998).

\section{Çöküșün sancıları: ırkçılıktan milliyetçiliğe, kadın düșmanlığından homofobiye}

Spencer, 1995 yılında, Mathieu Kassovitz'in Protesto'sunun Fransa'daki ilk gösteriminin yapılmasıyla filmin kaba yoksulluk masalının, ırkçılık ve polis gaddarlığının, haklarından mahrum bırakılmış anti-kahramanlarını kendilerine çok yakın gören banliyö izleyicileri içinde ayaklanmayı harekete geçirdiğini belirtir. Noé'in de anlaşma yanlısı olmayan ilk filmiyle aynı güçlü etkiyi uyandırma arayışında olduğunu söyler. Herkese Karşı Tek Başına filminin garip bir şekilde hem sağ hem de sol kanat tarafından övgü aldığını da ekler (Spencer, 1999). Filmin iki taraftan da övgü alması şaşırtıcı değildir, çünkü kasabın iç monologları, sağcı grupları coşkuyla ayaklandıracak ölçüde serttir. Öte yandan kasabın yabancılara ve eşcinsellere karşı nefretine rağmen hiçbir başarı elde edemeyen, sıradan bir kaybeden oluşu da sol kanadın tesellisi durumundadir.

Kasap, Paris'te bir barda oturup kahve içerken, bara giren bıyıklı, Arap olması muhtemel, bir müşteri barmenden kahve ister. Ama barmen kahvesinin olmadığını, başka yere gitmesini söyler, bıyıklı adam da doğal olarak kasabın önündeki kahveyi gösterip kendisine neden servis yapmadığını sorar. Sonunda barmen niyetini açıkça belli eder ve dükkânından gitmesini, yoksa başının belaya gireceğini söyler. Kasap bu sahnede kafasını öne eğip kahvesine bakar, barmenin yaptığından utanmış gibidir ama yabancılara karşı tutumu her ne kadar eyleme yansımasa da barmenden farklı değildir. Filmin sonlarına doğru, barda kavga ettiği baba oğuldan intikam almayı düşünen kasabın aklından geçirdiği düşünceler Fransa'daki "yabancı" düşmanlığına dair ipuçları verir: "Hangi lağımdan çıktıklarını bilmiyorum, fakat Fransıza benzemiyorlar. Baba, İsa figürlü haç takıyordu. Belki İspanyol veya Portekizli bir çiftçidir. Bazıları Fransa'ya sızmak için isimlerini ve dinlerini değiştirirler. Fakat ben Fransız'ım, onlara biraz asilik öğreteceğim." Bu cümleler aslında 
bazı Fransızların aynı dili konuşup aynı dine inansalar bile kendilerine benzemeyenleri asla Fransız olarak görmediklerini gösterir. Noé de aynı düşünceyi yaptığı bir röportajda şu sözlerle ifade eder:

Bugün Fransa'da olup Brezilya'da ya da başka ülkelerde olmayan bir şey var. Tıpkı... Sadece Avrupa' da bulacağınız bir çeşit bencillik var (...)

Fransa'da, tuhaf, çünkü azınlıklar Kuzey Amerika'daki azınlıklar gibi davranmıyor. Sadece bütünün bir parçası olmak istiyorlar. Ayrıca Fransa'da çok tuhaf bir şey var. Mesela bazı insanlar "Bu adam Fransız, bu adam Yahudi" gibi şeyler söyler. Sanki aynı anda hem Yahudi hem de Fransız olamazsınız. Eğer adam siyahsa, Fransız demezler. Onun yerine siyah derler. Ne zaman Fransız derlerse bu demektir ki adam beyazdır ve büyükbabaları da Fransız'dır (Judell, 1998).

Kendisi de Arjantin asıllı olan, New York'ta büyüyen ve 13 yaşında ailesiyle Fransa'ya yerleşen Noé'nin Fransa'daki azınlıklar hakkındaki bu görüşlerinde kendi deneyimlerinden izler olması muhtemel. Noé, filminin anti- Fransız olduğunu ve bu filmle Fransa'nın onurunu zedelemek istediğini, hatta filmin yasaklanmasının onu memnun edeceğini bile söyler (Spencer, 1999). Film, politik yanı her ne kadar ağır basmasa da basit bir dille Fransa hakkında çok şey anlatır. Fransa tüm azınlıkların mutlu mesut yaşadığı, herkesin Fransa için savaştığı bir ülke değildir. Her şeyiyle çamura batmış, beş parasız kalmış kasap bile dilenmeyi aklına getirdiği sahnede ülkesine olan sevgisini, azınlıklara olan nefretini aklından geçirir, hatta otel odasındaki son sahnede, psikolojik olarak dibe vurmuşken bile "Başbakan olacağım Fransa'yı yöneteceğim” cümlesi geçer aklından. Kasap her çukura düşüşünde bunun gibi, içini milliyetçilik coşkusuyla dolduracak düşünceler geçirir aklından. Milliyetçilik, erkek kimliğinin sert biçimde kendini gösterdiği alanlardan birisidir. Milliyetçi olmak, 1rkçı olmak aynı zamanda sert bir erkek olmayı da beraberinde getirir. Aksi taktirde bir erkek olarak milliyetçi bir gurubun içine girmek mümkün değildir. Bu nedenledir ki birçok ülkede eşcinsel hakları ve kadın hakları gibi hareketler hep sol kanat içinde yükselmiştir. Kasap da ekonomik nedenlerden dolayı kaybettiği erkekliğini ülkesine ve ırkına duyduğu bağlılıkla kapatmaya çalışır.

Bir başka önemli konu da kasaptaki kadın düşmanlığı ve artan homofobik düşünceleridir. Morris (1999), kasabın sevgilisini yumruklarken ve barda bir çocuğa sataştığında homofobik yanını açığa çıkartırken bir şeyin onu tahrik ettiğini söyler. Kasabın kadın düşmanı ve homofobik olduğunun belirtileri Carne'deki bazı sahnelerde kendini gösterir, bu özellikler onda bir anda ortaya çıkmamıştır. Ama Herkese Karşı Tek Başına filminde kadın düşmanlığı artık eyleme dönüşür; kasap sevgilisini döverek ekonomik anlamda 
kaybettiği otoritesini tekrar kazanmak ister, aynı zamanda dünyaya bir bebek getirmeyi de önlemiş olur. Bebek istememesi aslında kasabın tüm insanlardan nefret etmesinin sembolüdür. Ona göre anneler yalnızca süt verdiği için, babalar sadece para verdiği için, kadınlar da erkeklerin aletini rahatlattığı için sevilir. Fazlasıyla pragmatist bu bakış açısı kasabı gittikçe artan bir nihilizme ve şiddete sürükler. "Kadınlar bazen çok aşağılık olabiliyor" dediğinde ise kendisini ve kızını Portekizli bir adam için terk eden sevgilisini düşünür. Annesi de o daha bebekken kasabı terk etmiştir. Kasabın kadın düşmanı olmasının altında bunun gibi terk edilmelerin önemli yeri vardır. Ama asıl neden ekonomik yönden tatmin edilemeyen erkekliğin sekteye uğramasıdır.

Filmde kasabın homofobik eylemlerinin öne çıtığı iki önemli sahne vardır, ilginç bir şekilde ikisinin de altında ekonomik nedenler yatar. İlk sahnede kasap, at kesimhane yöneticisinden iş istedikten sonra yöneticinin bir ay sonra gel iş başı yap demesine rağmen (o daha erken işe başlamayı ister) sabıkası olup olmadığını sorduğu için, yönetici hakkında onun eşcinselliğiyle ilgili hakaret dolu cümleler geçirir aklından. Hatta yöneticinin eşcinsel oluşunun Fransız erkeklerine yapılan bir hakaret olduğunu bile düşünür. Oysa yönetici daha önce hiçbir işverenin yapmadığını yapar, ona geç de olsa işe başlamasını söyler, hem de sabıkası olmasına rağmen. Burada Noé'nin sinema dilini kullanmadaki becerisi ön plana çıkar. Bu sahneden önce, kasap dükkanındaki ve mezbahadaki iş isteme sahnelerinde dükkan sahipleri kasabı aşağılayarak geri çevirirler. Kasap ezilip büzülüp bir şeyler demeye çalışırken lafı kesilir, "hayır sana yardım edemem" gibi sert tepkilerle karşılaşır. Oysa yönetici onu dinler, sabıkası olmasına rağmen onu bir ay sonra başlamak üzere işe alır. Diğer adamlar kasabı o kadar aşağılamasına rağmen kasap tepki vermez, çünkü onlar eşcinsel değildir. Kasabın homofobik yanı burada iyice açığa çıkar, görüşmeden çıktıktan sonra bir eşcinsel bana nasıl böyle davranır diye düşünür ve bu fikir onu yöneticiyi öldürme düşüncesine kadar götürür. Çünkü takım elbiseli, masası ve sandalyesi olan, iyi bir işe sahip eşcinsel karşısında ezilmek onun erkekliğini zedelemiştir.

İkinci örnek ise barda genç bir erkek ve onun babasıyla kavga ettiği sahnedir. Kasap bir barın önünden geçerken cebindeki paraya bakar, yaklaşık 11 frank kalmıştır, bara girip içki içer, hesabı sorduğunda 12 frank cevabını alır. Cebinden çıkardığı bozuk paraları masanın üzerine koyar ve "11.20 versem?" der, bu sırada hemen yanındaki gözlüklü genç erkek hafifçe güler. Paraları sayarken yeterince yerin dibine girmişken, buna bir de gencin alaycı gülümsemesi eklenince kasap iyice çileden çıkar. O da diğer erkeklerin yap- 
tığı gibi, sözlü şiddet yoluyla, karşısındakinin eşcinsel olduğunu kastederek erkeklik onurunu kurtarmayı dener ve karşısındaki genci "Benimkini emmek ister misin?”, “İbne” gibi sözcüklerle tahrik eder. Kasap daha önce de aklından homofobik düşünceler geçirir ama sadece ekonomik anlamda çöküp, erkekliğinin hasar gördüğünü hissettiği anlarda bu düşüncelerini dışarı vurur.

\section{Ensest fantezi}

Sen benim küçük kızımsın ve ben seni... kadın yapacağım. ${ }^{18}$

Garip bir şekilde filmle ilgili yapılan eleştirilerde kasabın kızıyla ilişkiye girdiğini hayal ettiği sahneler ve kızıyla kurmak istediği cinsel ilişkiyi meşrulaştırmak için söyledikleri üzerine durulmamıştır. Bu sekansın adının geçtiği cümleler de genelde genç kızın boğazından akan kanlarla ilgilidir. ${ }^{19}$ Bunun birkaç nedeni olabilir; ya ensest ilişkinin ele alınması zor bir konu oluşu ya eleştirmenlerin bu sahneyi fazla ciddiye almamaları ya da her şeyin hayal olmasının onları biraz olsun rahatlatması. Carne'de ilk sinyallerin verilmeye başlandığı kasaptaki ensest arzu, filmin en rahatsız edici özelliğidir, seyirci ilk filmden itibaren büyük bir gerilimle kasabın kızıyla cinsel ilişkiye gireceği anın gelmesinden çekinir ve nihayet $o$ an geldiğinde ise Noé her şeyin bir hayal olduğunu gösterir. Ama seyirciyi yine rahatlatmaz. Çünkü hayalinde kızıyla cinsel ilişkiye giren kasap, gerçekte ise küçük tacizlerde bulunur; kızın göğüslerine dokunur, boynunu arzuyla öper. Son cümleleri ise kızıyla arasındaki ilişkiyi meşrulaştırmaya yöneliktir. Ona göre kızıyla birlikte olmasında hiçbir sakınca yoktur, her şey ikisi arasında kalacaktır. Onlar bunu yapsa da yapmasa da dünya değişmeyecektir. ${ }^{20}$ Daha ironik olansa babası ağlamaya başlayıp kızı ona sarıldığında film boyunca hissedilen gerilimli havanın fonda

18 Kasap, otel odasında kurduğu hayal sonrasında otelin balkonuna çıkar, arkasından kızı gelir babasına sarılır. Kasap uslanmak bilmeyen bir sapık gibi kızının sarılmasından yararlanıp göğüslerini okşar. Ardından uzunca düşünceler geçirir aklından, bu cümle de o düşüncelerden biridir.

19 Yapılan yorumlarda "Dikkat! Filmdeki görüntülerden uzaklaşmanız için 30 saniyeniz var" uyarısının sadece kızın boynundan akan kanlar için verildiği fikri hakimdir, oysa aynı uyarı kasapla kızının ensest ilişkisi için de verilmiştir.

20 Yönetmenin 2002 yapımı Dönüß̧̧ Yok filminin açılış sahnesinde, Herkese Karşı Tek Başına' da muallakta kalan ensest ilişkinin gerçekleştiğini öğreniriz. Kasap (Philippe Nahon) odadaki yatağında bir adamla konuşur, üzerinde sadece iç çamaşırı vardır. Adama bir süre hapis yattığını, çünkü kızıyla ilişkiye girdiğini söyler, daha sonra kamera onları terk eder, aşağı kattaki barın kapısına doğru yönelir. Noé bu sahneyle birlikte kasap dosyasını tamamen kapatmış olur. 
çalan umut vaat eden klasik müzikle ${ }^{21}$ son bulmasıdır. Müzik devam ederken baba kız birbirine sarılır, kasap ağlamaya devam eder, bir yandan da kızını öper. Bu sahne "ahlâk" yazısıyla kesilir, fondaki müzik devam ederken bulanık görüntülerde kasap, eteğinin altından kızının bacaklarını okşar. Ardından sahne "İnsanlığın ahlâkı vardır" yazısıyla ve buna eşlik eden uyarı sesiyle son kez kesilir. Kasap balkondadır, müzik kesilmiştir, kızı arkasındadır. Ama müziğin etkisi, kameranın balkondaki baba kızdan hayatın akıp gittiği caddeye çevrinmesiyle devam eder, dışarıda hâlâ umut vardır.

\section{Sonuç}

Gaspar Noé'nin her iki filmde başarılı biçimde kullandı̆̆ı farklı sinema dili onu başarıya götüren en önemli etmendir. Özellikle uyarıcı yazılar, hızlı kamera hareketleri ve buna eşlik eden şok edici sesler belirgin bir fark yaratır. Ama bunların hiçbirisi yukarıda ele alınan temaları güçlendirmede, kasabın bilincinin aktığı iç monologlar kadar etkili değildir. Noé, kasabın bitmek tükenmek bilmeyen monologları ile seyirciye olan biteni düşünme şansı vermez, izleyici kasabın hayal dünyasında onunla birlikte yuvarlanır. Noé, adeta bir psikiyatr gibi hasta ruhlu kasabın bilinçaltına ulaşmak için onu hipnotize edilmiş biçimde konuşturur. Dolayısıyla iki filmde de seyirci ve kasap arasındaki ilişki psikiyatr ve hasta arasındaki ilişki gibidir. Hasta gerçek bir hastanın özelliklerine sahiptir ve tüm açık sözlülüğüyle içini döker ama seyircilerin bir psikiyatr gibi filmi izlemesi çoğu zaman mümkün değildir. Seyircinin, filmin akışına, daha doğrusu kasabın düşüncelerinin akışına kapılıp, kendisini kasabın yerine koyma tehlikesi vardır. Bu, Noé'nin bir oyunudur, film boyunca nerdeyse kasaptan başka hiç kimseyi görmeyiz, hiç kimseyi duymayız, bir süre sonra kasaba acımaya başlarız, daha sonra acımanın yerini güçlü bir empati alır, empatiyle birlikte büyük bir vicdan azabı duyarız. Çünkü kasabın beynindeyizdir; onun sapkın düşüncelerinin acısını çekeriz. Steve Rose (2010) bir bakıma bu fikri destekler, ona göre Noé sinemayı sadece duygusal bir tepki uyandırmak için değil psikolojik bir tepki uyandırmak istediği için de kullanır.

Filmin asıl başarısı kahramanının bir hasta gibi kamera karşısına oturtulup tanısının izleyici tarafından konulmasının beklenmesidir. Böylece toplumsal cinsiyet alanında çokça malzeme veren bir karakteri derinlemesine inceleme şansını yakalamış oluruz. Bu inceleme sonucunda ortaya çıkan sonuç

21 Canon in D Major (Johann Pachelbel). 
ise açıktır: Hegemonik erkeklikler sistemik biçimde kodlandırılmış bir takım toplumsal değerler üzerinden sürekli olarak yeniden inşa edilerek sürdürülmektedir. Bu sürecin sürekliliği içinse alternatif savunma mekanizmaları ataerkil sistem içinde farklı yöntemlerle üretilmektedir. Sözlü ya da fiili şiddet ise bu savunma mekanizmalarının en son halkasını temsil etmektedir. Sonuç olarak kasap karakteri gösteriyor ki erkeklik krizi, kadınların kamusal alanda daha görünür olmasıyla ve ekonomik ayrıcalıkların kaybedilmesiyle birlikte hegemonik erkeklikleri zedeleyen yaygın bir virüs haline gelmiştir. 


\section{Kaynakça}

AKÇA, E. B. ve TÖNEL, E. (2011) Erkek(lik) çalışmalarına teorik bir çerçeve: feminist çalışmalardan hegemonik erkekliğe. ERDOĞAN, İ. (der.) içinde. Medyada hegemonik erkek(lik) ve temsil. İstanbul: Kalkedon.

BAILEY, M. (2003) Gaspar Noe. Senses of cinema. 17 Ekim 2013. http:// sensesofcinema.com/2003/great-directors/noe [Erişim tarihi: 11/02/2014].

BUTLER, J. (2012) Cinsiyet belası. Çev: Başak Ertür. İstanbul: Metis Yayınları.

CUDWORTH, E. (2008) Most farmers prefer blondes: the dynamics of anthroparchy in animals' becoming meat. Journal for Critical Animal Studies, 6 (1), s.32-45.

DEKESEREDY, W. S. ve SCHWARTZ, M. D. (2005) Masculunities and interpersonal violence. KIMMEL, M. S., HEARN, J. R. ve CONNEL, R. W. (der.) içinde. Handbook of studies on men masculinities. Londra: Sage.

GRAHAM, B. (1999) Portrait of a pathetic soul/"I stand alone" a bold tale of hate. San Francisco Chronicle. 11 Haziran 1999. http:/ / www.sfgate.com/movies/ article/ Portrait-of-a-Pathetic-Soul-I-Stand-Alone-a-2926536.php [Erişim tarihi: 11 Şubat 2014].

HOLDEN, S. (1998) Film festival review; a hard one to watch, even harder to live. The New York Times. 26 Eylül 1998. http:/ / www.nytimes.com/1998/09/26/ movies / film-festival-review-a-hard-one-to-watch-even-harder-to-live.html [Erişim tarihi: 11 Şubat 2014].

JUDELL, B. (1998) "I stand alone" with Gaspar Noe, US distribs nearing. Indiewire. 29 Eylül 1998. http://www.indiewire.com/article/i stand alone with gaspar noe us distribs nearing [Erişim tarihi: 11 Şubat 2014].

LUKE, B. (2007) Brutal: manhood and the exploitation of animals. Illinois: University of Illinois Press.

MACNAMARA, J. R. (2006) Media and male identity the making and remaking of men. Londra: Palgrave Macmillan.

MERRIMAN, B. (2010) Gender differences in family and peer reaction to the adoption of a vegetarian diet. Feminism and Psychology, 20 (3), s.420-427.

MILJKOVITCH, R., DANET, M. ve BERNIER, A. (2012) Intergenerational transmission of attachment representations in the context of single parenthood in France. Journal of Family Psychology, 26 (5), s.784-792.

MORRIS, W. (1999) Neck-deep in the heart of a killer. San Francisco Chronicle. 11 Haziran 1999. http:/ / www.sfgate.com/news/article/Neck-deep-in-the-heartof-a-killer-3079827.php [Erişim tarihi: 11/02/2014]. 
ÖZTÜRK, S. R. \& TUTAL, N. (2001) Sinemada kadın karakterlerin sessizliği: sessizlik bir direnme pratiği olabilir mi?. İletişim 10, s.101-126.

PARRY, J. (2010) Gender and slaughter in popular gastronomy. Feminism $\mathcal{E}$ Psychology, 20 (3), s.381-396.

POLAT, N. (2008) Cinsiyet ve mekân: erkek kahveleri. Toplum ve Bilim, 112, s.147-157.

POTTS, A. ve PARRY, J. (2010) Vegan sexuality: challenging heteronormative masculinity through meat-free sex. Feminism \& Psychology, 20 (1), s.53-72.

RIDING, A. (1999) Film; Nihilism gets a butcher's face, france a jolt of realism. The New York Times. 14 Mart 1999. http:/ / www.nytimes.com/1999/03/14/ movies / film-nihilsm-gets-a-butcher-s-face-france-a-jolt-of-realism. html?pagewanted=all\&src=pm [Erişim tarihi: 11 Şubat 2014].

ROGERS, R. (2008) Beasts, burgers, and hummers: meat and the crisis of masculinity in contemporary television advertisements. Environmental Communication: A Journal of Nature and Culture, 2(3), s.281-301.

ROSE, S. (2010) Gaspar Noe: what's the problem? The Guardian. 16 Eylül 2010. http://www.guardian.co.uk/film/2010/sep/16/gaspar-noe-enter-the-void [Erişim tarihi: 11 Şubat 2014].

ROTHGERBER, H. (2012) Real men don't eat (vegetable) quiche: masculinity and the justification of meat consumption. psychology of men $\mathcal{E}$ masculinity [Çevrimiçi]. http:/ / foodethics.univie.ac.at/fileadmin/ user upload/p foodethik/ Rothgerber Hank 2012. Real Men Dont Eat -Vegetable- Quiche. Masculinity and the Justification of Meat Consumption.pdf [Erişim tarihi: 11 Şubat 2014].

SOBAL, J. (2005) Men, meat, and marriage: models of masculinity. Food and Foodways, 13(1), s.135-158.

SPENCER, L. (1999) Cinema to dishonour france. The Independent. 14 Ocak 1999. http: / / www.independent.co.uk/arts-entertainment/ cinema-to-dishonourfrance-1046932.html [Erişim tarihi: 11 Şubat 2014].

STERRITT, D. (2007) "Time destroys all things": an interview with Gaspar Noé. Quarterly Review of Film and Video 24(4), s.307-316.

SYZDEK, M. R. ve M. E. ADDIS (2010) Adherence to masculine norms and attributional processes predict depressive symptoms in recently unemployed men. Cognitive Therapy and Research, 34(6), s. 533-43. 